\title{
Effect of Sources and Levels of Sulphur on Growth, Yield and Quality of Summer Sesame under South Gujarat Condition (Sesamum indicum L.)
}

\author{
N.N. Parmar, A.P. Patel* and Mahaveer Choudhary \\ Department of Agronomy, College of Agriculture, Navsari Agricultural University, \\ Navsari 396 450, Gujarat, India \\ *Corresponding author
}

\section{A B S T R A C T}

Keywords

Sources and levels of sulphur, Growth and yield attributes, Economics

Article Info

Accepted:

24 January 2018

Available Online:

10 February 2018
A field experiment was conducted during summer season of 2015-16 at the Hill millet research station N.A.U., waghai, with twelve treatment combinations consisting of three sources of sulphur viz., $\mathrm{A}_{1}$ : Elemental sulphur, $\mathrm{A}_{2}$ : Gypsum and $\mathrm{A}_{3}$ : Ammonium sulphate and four levels of sulphur viz., $\mathrm{S}_{0}: 0 \mathrm{~kg} \mathrm{ha}^{-1}, \mathrm{~S}_{1}: 10 \mathrm{~kg} \mathrm{ha}^{-1}, \mathrm{~S}_{2}: 20 \mathrm{~kg} \mathrm{ha}^{-1}, \mathrm{~S}_{3}: 30 \mathrm{~kg} \mathrm{ha}^{-1}$ were evaluated with factorial randomized block design with three replications. Almost all the growth, yield $\left(828.72,824.73 \mathrm{~kg} \mathrm{ha}^{-1}\right)$ and quality attributes were significantly highest recorded with application of ammonium sulphate $\left(\mathrm{A}_{3}\right)$ source and $30 \mathrm{~kg} \mathrm{ha}^{-1}\left(\mathrm{~S}_{3}\right)$ levels of sulphur, while maximum BCR was recorded with source like ammonium sulphate $\left(\mathrm{A}_{3}\right)$ and in levels of sulphure gave higher benefit with $\left(\mathrm{S}_{2}\right),\left(\mathrm{S}_{3}\right)$ treatment.

\section{Introduction}

Sesame (Sesamum indicum L.) is also popularly known as sesame, til, simsim, benised, gingelly, gergelim, etc. Africa has been considered as the centre of origin of this crop (Joshi, 1961). It is generally cultivated throughout the year, i.e., during Kharif, semi Rabi and Summer as a sole as well as mixed/inter crop. It is one of the most preferred oilseed crops under rainfed condition even with low yield level because of its higher price and good quality oil. Sesame is known as "The queen of the oilseed crops" due to excellent quality of its oil, flavor, taste and softness. It is considered to have both nutritional and medicinal values. Sulphur plays a remarkable role in protein metabolism. It is required for the synthesis of proteins, vitamins and chlorophyll and also $S$ containing amino acids such as cystine, cysteine and methionine which are essential components of protein. Among the sulphur supplying sources, gypsum and elemental sulphur are being abundantly used in sulphur deficient soils. The response of sesame to sulphur for producing higher yield was up to $40 \mathrm{~kg} \mathrm{ha}^{-1}$ according to Nagawani et al., (2001) and Kathiresan (2002). Sulphur application not only improved the grain yield 
but also improved the quality of crops. Use of high analysis sulphur free fertilizers, heavy sulphur removal by the crops under intensive cultivation and neglect of sulphur replenishment contributed to widespread sulphur deficiencies in arable soils. Hence, this study was attempted to study the importance of sulphur in realizing the better growth, yield and quality of sesame crops.

\section{Materials and Methods}

A field experiment was conducted during summer season of the year 2015-16 at the Hill millet research station N.A.U., Waghai (Dangs), Gujarat. The soil of experimental field was clayey in texture, low in available nitrogen (197.26 kg ha $\mathrm{kg}^{-1}$ and available phosphorus (30.93 kg ha-1) and high in available potassium $\left(369.80 \mathrm{~kg} \mathrm{ha}^{-1}\right)$. Twelve treatment combinations consisting of three levels of sulphur viz., $\mathrm{A}_{1}$ : Elemental sulphur, $A_{2}$ : Gypsum and $A_{3}$ : Ammonium sulphate and four levels of sulphur viz., $\mathrm{S}_{0}: 0 \mathrm{~kg} \mathrm{ha}^{-1}, \mathrm{~S}_{1}: 10$ $\mathrm{kg} \mathrm{ha}^{-1}, \mathrm{~S}_{2}: 20 \mathrm{~kg} \mathrm{ha}^{-1}, \mathrm{~S}_{3}: 30 \mathrm{~kg} \mathrm{ha}^{-1}$ were evaluated with factorial randomized block design with three replications. Sesame variety GT-2 was selected for the investigation as test crop.

Furrow was opened manually in each plot by keeping spacing $45 \mathrm{~cm}$ between two rows. Recommended dose of fertilizer used for sesame was 25:50:00 NPK ha-1 in the form of urea and DAP in all the experimental plots. The four levels $\left(0,10,20,30 \mathrm{~kg} \mathrm{ha}^{-1}\right)$ of different sources of sulphur (elemental sulphur, gypsum and ammonium sulphate) were applied in combination to plots along the other fertilizers as per layout plant. Full dose of phosphorus, sulphur and nitrogen were applied at sowing. The crop was sown on $20^{\text {th }}$ February, 2016 and harvested on $6^{\text {th }}$ june, 2016, observation on seed yield and stalk yield were estimated at harvest and expressed as mean.

\section{Results and Discussion}

\section{Growth and yield attributes}

Plant population, Plant height (30 DAS), No. of capsule, No. of seed capsule, were not significantly influenced due to application of different sources of sulphur. Treatment A3: Ammonium sulphate recorded significantly higher plant population (at harvest), plant height (60, at harvest), no of branches $(30,60$, at harvest), capsule length, seed yield but it was significantly at par with treatment A2: Gypsum. Increased in plant height might be due to more synthesis of amino acids in chlorophyll content in growing region and improving the photosynthetic activity. This was evidenced through the studies of Debye and Khan (1993). Among the sulphur carriers, Ammonium sulphate proved better for obtaining higher seed yield which might be due to its higher solubility (Venkatesh et al., (2002), Patel et al., (2002) and Verma et al., (2012). might be attributed to better availability of Sulphur to plant at different crop growth stages and thus enhanced the yield attributes. These results are in accordance with the finding of Duhoon et al., (2005).

Plant population, Plant height (30 DAS), No. of capsule, No. of seed capsule, stalk yield were not significantly influenced due to application of different levels of sulphur. Treatment S3: $30 \mathrm{~kg} \quad \mathrm{~S} \quad \mathrm{ha}^{-1}$ recorded significantly higher plant population (at harvest), plant height (60, at harvest), no of branches (30, 60, at harvest), capsule length, seed yield but it was significantly at par with treatment S2: $20 \mathrm{~kg} \mathrm{~S} \mathrm{ha}^{-1}$. Increase in plant height may be due to better nutritional environment for plant growth at active vegetative stages as a result of improvement in root growth, cell multiplication, elongation and cell expression in the plant body, which ultimately increased the plant height (Table 1). 
Table.1 Growth attributes of sesame under sources and levels of sulphur

\begin{tabular}{|c|c|c|c|c|c|c|c|c|}
\hline \multirow[t]{2}{*}{ Treatments } & \multicolumn{2}{|c|}{ Plant population } & \multicolumn{3}{|c|}{ Plant height (cm) } & \multicolumn{3}{|c|}{ Number of branches plant ${ }^{-1}$} \\
\hline & Initial & At harvest & 30 DAS & 60 DAS & At harvest & 30 DAS & 60 DAS & At harvest \\
\hline \multicolumn{9}{|l|}{ Sources of Sulphur } \\
\hline $\mathbf{A}_{1}$ : Elemental sulphur & 35.37 & 32.21 & 33.92 & 59.92 & 86.08 & 4.00 & 8.23 & 13.26 \\
\hline $\mathbf{A}_{2}:$ Gypsum & 36.41 & 34.25 & 35.50 & 64.38 & 91.00 & 4.60 & 8.97 & 14.30 \\
\hline $\mathbf{A}_{3}$ : Ammonium sulphate & 37.44 & 36.28 & 37.08 & 68.84 & 95.91 & 5.20 & 9.71 & 15.34 \\
\hline S.Em. \pm & 0.68 & 0.77 & 0.96 & 1.82 & 2.51 & 0.12 & 0.27 & 0.41 \\
\hline C.D. at 5\% & NS & 2.27 & NS & 5.35 & 7.36 & 0.36 & 0.80 & 1.20 \\
\hline \multicolumn{9}{|l|}{ Levels of Sulphur } \\
\hline $\mathrm{S}_{0}: 0 \mathrm{~kg} \mathrm{ha}^{-1}$ & 35.43 & 32.32 & 34.00 & 60.17 & 85.76 & 4.03 & 8.27 & 13.32 \\
\hline$S_{1}: 10 \mathrm{~kg} \mathrm{ha}^{-1}$ & 35.77 & 33.00 & 34.53 & 61.65 & 87.59 & 4.23 & 8.52 & 13.67 \\
\hline$S_{2}: 20 \mathrm{~kg} \mathrm{ha}^{-1}$ & 37.04 & 35.49 & 36.47 & 67.11 & 94.36 & 4.97 & 9.42 & 14.93 \\
\hline $\mathrm{S}_{3}: 30 \mathrm{~kg} \mathrm{ha}^{-1}$ & 37.38 & 36.17 & 37.00 & 68.59 & 96.26 & 5.17 & 9.67 & 15.28 \\
\hline S.Em. \pm & 0.78 & 0.89 & 1.11 & 2.10 & 2.90 & 0.14 & 0.31 & 0.47 \\
\hline C.D. at 5\% & NS & 2.62 & NS & 6.17 & 8.50 & 0.42 & 0.92 & 1.39 \\
\hline C.V. $\%$ & 6.43 & 7.81 & 9.37 & 9.81 & 9.55 & 9.23 & 10.50 & 9.92 \\
\hline Interaction & NS & NS & NS & NS & NS & NS & NS & NS \\
\hline
\end{tabular}

Table.2 Yield attributes of sesame under sources and levels of sulphur

\begin{tabular}{|c|c|c|c|c|c|}
\hline Treatments & No. of capsule plant ${ }^{-1}$ & Capsule length (cm) & No. of seeds capsule ${ }^{-1}$ & $\begin{array}{c}\text { Seed yield } \\
\left(\mathrm{kg} \mathrm{ha}^{-1}\right)\end{array}$ & $\begin{array}{c}\text { Stalk yield } \\
\left(\mathrm{kg} \mathrm{ha}^{-1}\right)\end{array}$ \\
\hline \multicolumn{6}{|l|}{ Sources of Sulphur } \\
\hline $\mathbf{A}_{1}$ : Elemental sulphur & 35.33 & 4.41 & 49.68 & 685.21 & 1610.35 \\
\hline $\mathbf{A}_{2}:$ Gypsum & 36.80 & 5.63 & 50.94 & 756.96 & 1727.17 \\
\hline $\mathbf{A}_{3}:$ Ammonium sulphate & 38.27 & 6.84 & 52.20 & 828.72 & 1843.98 \\
\hline S.Em. \pm & 1.04 & 0.15 & 0.93 & 22.56 & 57.51 \\
\hline C.D. at $5 \%$ & NS & 0.43 & NS & 66.17 & 168.69 \\
\hline \multicolumn{6}{|l|}{ Levels of Sulphur } \\
\hline$S_{0}: 0 \mathrm{~kg} \mathrm{ha}^{-1}$ & 35.41 & 4.48 & 49.75 & 689.19 & 1616.84 \\
\hline$S_{1}: 10 \mathrm{~kg} \mathrm{ha}^{-1}$ & 35.90 & 4.88 & 50.17 & 713.11 & 1655.78 \\
\hline$S_{2}: 20 \mathrm{~kg} \mathrm{ha}^{-1}$ & 37.70 & 6.37 & 51.71 & 800.81 & 1798.55 \\
\hline $\mathrm{S}_{3}: 30 \mathrm{~kg} \mathrm{ha}^{-1}$ & 38.19 & 6.77 & 52.13 & 824.73 & 1837.49 \\
\hline S.Em. + & 1.20 & 0.17 & 1.07 & 26.05 & 66.41 \\
\hline C.D. at 5\% & NS & 0.49 & NS & 76.41 & NS \\
\hline C.V. \% & 9.81 & 9.00 & 6.32 & 10.32 & 11.53 \\
\hline Interaction & NS & NS & NS & NS & NS \\
\hline
\end{tabular}


Table.3 Quality and economics of sesame under sources and levels of sulphur

\begin{tabular}{|c|c|c|c|c|c|c|c|c|}
\hline Treatments & $\begin{array}{c}\text { Oil } \\
\text { content } \\
(\%)\end{array}$ & $\begin{array}{l}\text { Protein } \\
\text { content } \\
\qquad \%)\end{array}$ & $\begin{array}{l}\text { Oil yield } \\
\left(\mathrm{kg} \mathrm{ha}^{-1}\right)\end{array}$ & $\begin{array}{l}\text { Protein } \\
\text { yield (kg } \\
\text { ha }^{-1} \text { ) }\end{array}$ & $\begin{array}{l}\text { Gross } \\
\text { realization } \\
\left(\text { ₹ } \text { ha }^{-1}\right)\end{array}$ & $\begin{array}{l}\text { Cost of } \\
\text { cultivation } \\
\left(₹ \text { ha }^{-1}\right)\end{array}$ & $\begin{array}{c}\text { Net } \\
\text { realization } \\
\left.\text { (₹ } \text { ha }^{-1}\right)\end{array}$ & BCR \\
\hline \multicolumn{9}{|c|}{ Sources of Sulphur } \\
\hline $\begin{array}{l}\mathbf{A}_{1}: \text { Elemental } \\
\text { sulphur }\end{array}$ & 43.32 & 16.88 & 296.83 & 115.66 & 29018 & 19526 & 9492 & 1.48 \\
\hline $\mathbf{A}_{2}:$ Gypsum & 45.83 & 17.63 & 346.91 & 133.45 & 32005 & 17606 & 14399 & 1.81 \\
\hline $\begin{array}{l}\text { A }_{3} \text { : Ammonium } \\
\text { sulphate }\end{array}$ & 48.33 & 18.38 & 400.52 & 152.31 & 34992 & 17786 & 17206 & 1.96 \\
\hline S.Em. \pm & 0.60 & 0.10 & 14.68 & 4.70 & - & - & - & - \\
\hline C.D. at $5 \%$ & 1.75 & 0.30 & 43.04 & 13.79 & - & - & - & - \\
\hline \multicolumn{9}{|l|}{ Levels of Sulphur } \\
\hline $\mathrm{S}_{0}: 0 \mathrm{~kg} \mathrm{ha}^{-1}$ & 43.46 & 16.92 & 299.52 & 116.61 & 29184 & 17006 & 12178 & 1.71 \\
\hline $\mathrm{S}_{1}: 10 \mathrm{~kg} \mathrm{ha}^{-1}$ & 44.30 & 17.17 & 315.90 & 122.44 & 30180 & 17656 & 12524 & 1.70 \\
\hline $\mathrm{S}_{2}: 20 \mathrm{~kg} \mathrm{ha}^{-1}$ & 47.36 & 18.08 & 379.26 & 144.78 & 33830 & 18306 & 15525 & 1.84 \\
\hline $\mathrm{S}_{3}: 30 \mathrm{~kg} \mathrm{ha}^{-1}$ & 48.19 & 18.33 & 397.43 & 151.17 & 34826 & 18956 & 15870 & 1.83 \\
\hline S.Em. \pm & 0.69 & 0.12 & 16.95 & 5.43 & - & - & - & - \\
\hline C.D. at $5 \%$ & 2.02 & 0.34 & 49.70 & 15.92 & - & - & - & - \\
\hline C.V. \% & 4.52 & 1.99 & 14.61 & 12.18 & - & - & - & - \\
\hline Interaction & NS & NS & NS & NS & - & - & - & - \\
\hline
\end{tabular}


Significant increase in plant height with application might be attributed to indirect involvement of sulphur in the photosynthesis process of plants (Patil et al., 2014). The bioactivity of sulphur might have played important role in improving yield attributes like capsule per plant, length of capsule and there by seed yield per plant ultimately increase in seed and stalk yield. This finding was reported by Raja et al., (2007) (Table 2).

\section{Quality parameters and economics}

An application of sulphur with treatment $\mathrm{A}_{3}$ (Ammonium sulphate) resulted in higher oil content and oil yield. Similar result was reported by Tomar (2012). Protein content and protein yield of sesame were influenced significantly by the different sources of sulphur. Sulphur applied as $\mathrm{A}_{3}$ (Ammonium sulphate) were resulted in significantly highest protein content $(18.38 \%)$ and protein yield $\left(152.31 \mathrm{~kg} \mathrm{ha}^{-1}\right)$, Although, the three sources are containing $\mathrm{SO}_{4}$, when Gypsum is applied to soils, the presence of free $\mathrm{Ca}^{++}$ions in soil solution reduces its solubility as a result of common ion effect. Similar increase in protein content due to sulphur application through Ammonium sulphate was observed by Ventakesh et al., (2002) Sulphur applied at $30 \mathrm{~kg} \mathrm{ha}^{-1}$ resulted in highest oil content 48.19 $\%$ and protein content $18.33 \%$, respectively, which was at par with application of $S_{2}(20 \mathrm{~kg}$ $\mathrm{S} \mathrm{ha}^{-1}$ ) (Table 3). It might be due to involvement of sulphur in the synthesis of fatty acids and also increase protein quality through the synthesis of certain amino acids such as cysteine and methionine. It is evident from the result that sulphur had remarkable influence on protein and oil content. Similar finding was also reported by Havlin et al., 1999. The maximum gross realization of (₹ $34992 \mathrm{ha}^{-1}$ ), net realization of ( $₹ 17206 \mathrm{ha}^{-1}$ ) and BCR of (1.96) were secured with application of $\mathrm{A}_{3}$ (Ammonium sulphate) and with application of $S_{3}\left(30 \mathrm{~kg} \mathrm{~S} \mathrm{ha}^{-1}\right)$ got maximum gross realization of ( $₹ 34826 \mathrm{ha}^{-1}$ ), net realization of (₹ $15870 \mathrm{ha}^{-1}$ ). This might be due to more availability of sulphur through Ammonium sulphate which has increased the seed yield, stalk yield and quality of Sesame. These results are in accordance with the finding of Verma et al., (2012) and Ravi et al., (2008).

\section{References}

Dubey, O. P. and Khan, R. A. (1993). Effect of nitrogen and sulphur content in Indian mustard and their residual balance in soil. Indian journal of Agronomy 38: 582-587.

Joshi, A. B. (1961). Sesame monograph, Indian oilseed committee. Hyderabad, pp 1-4.

Nagavani, A. V., Sumathi, V., Chandrika, V and Muneendra Babu, A. (2001). Effect of nitrogen and sulphur on yield and oil content of sesame (Sesamum indicum L.) Journal of Oilseeds Research. 18(1): 73-74.

Patel, P. T., Patel, G. G. and Patel, G. A., Sonani, V. V. and Patel, H. B. (2002). Effect of sources and levels of sulphur on seed and oil yield of safflower (Carthamus tinctorius L.). Journal of Oilseeds Research. 19(1): 76-78.

Patil, S. S., Choudhary, A. A., Goley, A. V. and Rasal, S. J. (2014). Effect of phosphorus and sulphur on growth yield and economics of linseed. Journal of Soils and Crops. 24 (1): 159-164.

Raja, K., Omar, H., Gurusamy, L. and Suganya, S. (2007). Sulphur Levels on Nutrient Uptake and Yield of Sesame Varieties and Nutrient Availability. International Journal of Soil Science, 2: 278-285.

Ravi, S., Channal, H. T., Hebsur, N. S., Patil, B. N. and Dharmatti, P. R. (2008). Effect of sulphur, zinc and iron nutrition on growth, yield, nutrient uptake and 
quality of safflower (Carthamus tinctorius L.). Karnataka Journal of Agricultural Science. 21(3): 382-385.

Tiwari, R. K., Namdeo, K. N., Jha, Girish and Jha, G. (2000). Effect of nitrogen and sulphur on growth, yield and quality of sesame (Sesamum indicum) varieties. Res.On Crops. 1: (2) 163-167.

Tomar, R. S. (2012). Response of linseed (Linumus itatissium) to sources and doses of sulphur in alluvial soils of Madya Pradesh. Crop Research. 43 (13): 39-41.
Venkatesh, M. S., Majumdar, B., Lal, B. and Kailash Kumar. (2002). Relative performance of sulphur sources on sulphur nutrition of groundnut (Arachis hypogaea) in acid alfisol of Meghalaya. Indian journal of Agriculture sciences. 72(4): 216-219.

Verma, A. K., Shrivastava, G. K., Tripathi, V. K. and Kolhe, S. S. (2012). Response of safflower (Carthamus tinctorius L.) to sulphur fertilization in alfisols of Chhattisgadh plains. Journal of Oilseed Research. 29: 244-245.

\section{How to cite this article:}

Parmar, N.N., A.P. Patel and Mahaveer Choudhary. 2018. Effect of Sources and Levels of Sulphur on Growth, Yield and Quality of Summer Sesame under South Gujarat Condition (Sesamum indicum L.). Int.J.Curr.Microbiol.App.Sci. 7(02): 2600-2605. doi: https://doi.org/10.20546/ijcmas.2018.702.316 